\title{
Naturally-Occurring Zirconolites - Analogues for the Long-Term Encapsulation of Actinides in Synroc
}

\author{
By K. P. Hart ${ }^{1}$, G. R. Lumpkin ${ }^{1}$, R. Giere ${ }^{2}$, C. T. Williams ${ }^{3}$, P. J. McGlinn ${ }^{1}$ and T. E. Payne ${ }^{1}$ \\ 1 Australian Nuclear Science and Technology Organisation, PMB 1, Menai 2234, Australia \\ ${ }^{2}$ Mineralogisch-Petrographisches Institut der Universität, Bernoullianum CH-4056 Basel, Switzerland \\ ${ }^{3}$ Department of Mineralogy, The Natural History Museum, Cromwell Rd, London SW7 5BD, UK
}

(Received September 15, 1995; accepted March 13, 1996)

Natural analogues / Zirconolite / Radiation damage / Synroc / Actinides / Geochemical alteration

\section{Summary \\ The use of natural zirconolites to assess the effect of $\alpha$-decay damage and geochemical alteration on the release of actinides from HLW wasteforms is critically examined. There is evidence that the natural zirconolites provide a good chemical and radi- ation damage analogy for the HLW wasteforms, but additional work is required to define the geochemical environments in which zirconolite is stable or unstable (e.g., suffering corrosion or chemical alteration, including loss of actinides).}

\section{Introduction}

The long-term performance of high level wasteforms (HLW) under repository conditions is difficult to predict entirely from laboratory studies as these examinations cannot completely duplicate all of the complex interactions experienced by the wasteform in the natural environment or the radiation damage incurred over geological time. This study focuses on the ability of natural zirconolites to serve as analogues for the longterm encapsulation of actinides in the zirconolite phase in Synroc.

Synroc is a multiphase ceramic developed by ANU and ANSTO for the encapsulation of high level radioactive liquid waste. The major phases of Synroc are:

$\begin{array}{ll}\text { Phase } & \begin{array}{l}\text { Designed } \\ \text { to incorporate }\end{array} \\ \text { Zirconolite }-\mathrm{CaZrTi} \mathrm{O}_{7} & \mathrm{U}, \mathrm{Zr}, \mathrm{Np}, \mathrm{Pu}, \mathrm{RE} \\ \mathrm{Hollandite}^{-} \mathrm{Ba}\left(\mathrm{Al}_{2}, \mathrm{Ti}_{6} \mathrm{O}_{8}\right. & \mathrm{Cs}, \mathrm{Rb}, \mathrm{Ba} \\ \text { Perovskite }-\mathrm{CaTiO}_{3} & \mathrm{Sr} \text { and transuranics such } \\ & \text { as } \mathrm{Np} \text { and } \mathrm{Pu}, \mathrm{RE}\end{array}$

Titanium oxides and

other minor phases.

Previous work [1] has established that when actinides are incorporated into Synroc-C they partition preferentially, by factors between 5 and 10 , into zirconolite over perovskite. Zirconolite thus becomes the phase which is of most interest in studying the effects of radiation, in particular $\alpha$-decay damage, on the retention of actinides in the wasteform over the life of the repository.
Ewing et al. [2] note that these effects can be studied for ceramic wasteforms like Synroc by using naturally-occurring $\mathrm{U}$ - and Th-bearing phases that are structurally and chemically analogous to the wasteform phases. Natural zirconolites are rare but have been found in a number of locations [3, 4]. Generally they contain elevated levels of uranium and thorium (up to $25 \mathrm{wt} \% \mathrm{UO}_{2}$ and $18 \mathrm{wt} \% \mathrm{ThO}_{2}$ ) and can be used as the basis of an investigation on the disposal of Synroc and other zirconolite-rich ceramic high level wasteforms over exceptionally long periods of time.

This paper will attempt to determine whether it is possible, using natural zirconolite samples, to provide enough scientific evidence to allow a correspondence to be established between the behaviour of natural zirconolites in the geological environment and the performance of high level wasteforms under repository conditions. In doing so we will concentrate on comparing the data available for natural and synthetic (effect of radiation damage and alteration processes), with the overall aim of establishing whether geochemical interactions that are identifiable for natural samples are applicable to synthetic zirconolite phases.

\section{Phase chemistry}

Natural zirconolites have a complicated chemical composition [5], that may lead to complex zoning of uranium, thorium, and rare earth elements. Detailed analytical electron microscopy (AEM) analyses of natural zirconolites from Adamello (Italy) and Bergell (Switzerland) have shown that the elements occupying the $\mathrm{Ca}$-site show a wide variation. The phase chemistry of these zirconolites is compared to the average compositions of zirconolite in Synroc containing 10 and $20 \mathrm{wt} \%$ simulated HLW in Figure 1.

There has been some disagreement, however, about the site on which the actinides are located in natural and synthetic zirconolite samples. This is partly due to the fact that actinides can be forced onto either the $\mathrm{Ca}$ - or $\mathrm{Zr}$-site. Early studies [6, 7] concluded that, unlike natural zirconolites [5], the actinides were incorporated into the $\mathrm{Zr}$-site and not into the Ca-site although the results were not consistent with studies of $\mathrm{Cm}$-doped zirconolite [7] showing that $\mathrm{Cm}$ was located on the Ca-site. More recently, AEM analysis has 


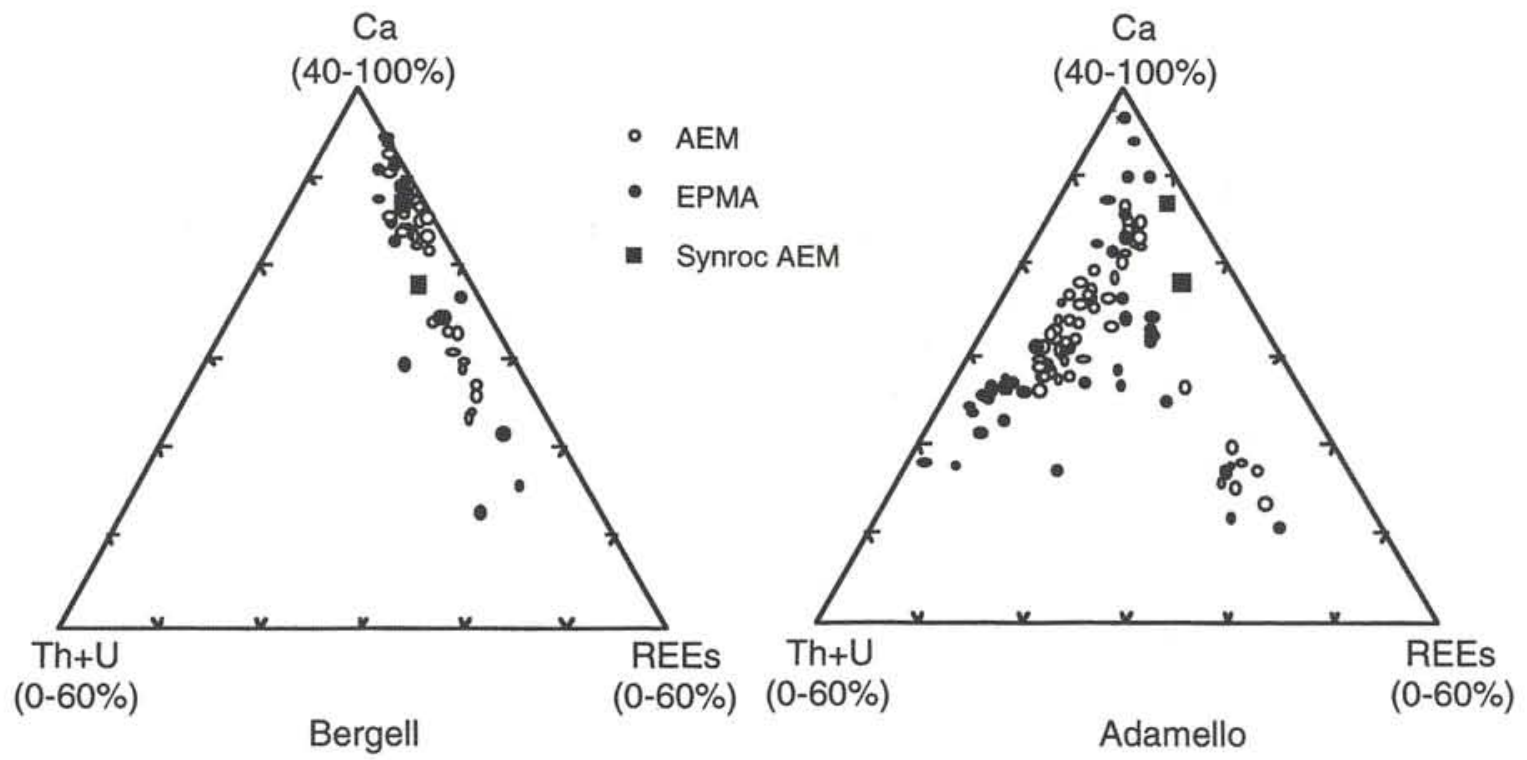

Fig. 1. Comparison of the phase chemistry of natural zirconolites with the average compositions of zirconolite in Synroc containing 10 and $20 \mathrm{wt} \%$ simulated HLW.

shown that, in samples of Synroc-C doped with $10 \mathrm{wt} \%$ simulated HLW, most of the U and REEs occupied the eight co-ordinated $\mathrm{Ca}$-site, balanced by nearly equal amounts of $\mathrm{Al}$ at the $\mathrm{Ti}$ sites. This is in agreement with findings on natural zirconolites from Bergell and Adamello [5]. At higher waste loadings small amounts of $\mathrm{U}, \mathrm{Gd}$, and especially Y may occupy the seven co-ordinated zirconium site [8]. Therefore, the substitution of actinide elements in Synroc-C preferentially occurs in the Ca-site, particularly at relatively low actinide loadings.

Given that there is overlap between the phase chemistry in the zirconolite phase in Synroc and in the natural samples, and that the substitution of actinides is occurring on the same site in both Synroc-C and natural samples, there is a reasonable chemical analogy between the natural and synthetic zirconolite.

\section{Radiation damage}

Natural zirconolites have been studied for the effect of radiation damage on their micro-structure using a variety of techniques. Recent studies [9], based on using AEM for chemical analysis and identification of microstructures, have shown that natural zirconolite samples undergo a crystalline to aperiodic transformation at doses of $10^{15}$ to $10^{16} \alpha \mathrm{mg}^{-1}$. This result is similar to earlier studies by other authors $[10,11]$ based on determining aperiodic structures from X-ray and electron diffraction.

Actinide doping produces similar radiation damage effects in synthetic specimens as those seen in natural samples. Laboratory studies carried out at Harwell, in the UK, and JAERI, in Japan, have used high dopings of short-lived actinides, ${ }^{244} \mathrm{Cm}$ and ${ }^{238} \mathrm{Pu}$, to simulate radiation damage in Synroc, perovskite and zirconolite. The work carried out at Harwell has shown that the volume expansion of zirconolite in specimens doped with $4 \%{ }^{244} \mathrm{Cm}$ or up to $10.4 \mathrm{wt} \%{ }^{238} \mathrm{Pu}$, saturates at about $4-7 \%$ at doses of around $5-10 \times 10^{15}$ $\alpha \mathrm{mg}^{-1}$, at ambient temperatures [12]. This dose range is slightly higher than that found for synthetic zirconolite by previous workers [7, 12, 13], and similar to those determined for natural zirconolites.

Storage of actinide-doped zirconolite at about $300^{\circ} \mathrm{C}$ slows the disordering process [14]. This result is similar to that obtained at JAERI for curium-doped zirconolite and Synroc stored at $200^{\circ} \mathrm{C}$ which showed that swelling imposed by a given dose was reduced by $30 \%$ [15]. As the storage temperature in repositories will to some extent be elevated, depending on the disposal scenario considered, the change in density and swelling measured in laboratories at room temperature should provide reliable, conservative data for performance assessments.

\section{Actinide retention}

\subsection{Natural zirconolites}

Actinide retention, in this paper, is defined as the ability of the structure over time to retain actinide elements. Some isotopic and leaching studies have been made on natural zirconolite samples $[3,16]$. The isotopic studies on aperiodic natural zirconolites demonstrate that they have generally remained as closed systems with respect to the migration of $\mathrm{U}-\mathrm{Th}-\mathrm{Pb}$ isotopes for time periods up to $5.5 \times 10^{8} \mathrm{yr}$ [3]. This result does not strictly apply to all these samples, as interpretation of some of the results required the assumption that other phases were present in the samples.

Leaching results on the same set of natural samples [16] indicate that for a relatively undamaged Kaiserstuhl zirconolite the $\mathrm{Ca}$ leach rate was about a factor 
of 10 lower than for the aperiodic sample from Sri Lanka. These results need to be confirmed on zirconolite grains that are well characterized before and after leaching so that the presence of inclusions or other phases does not affect the interpretation of leach data. In addition, leach rates of actinide elements should be measured for natural zirconolites. To address these shortfalls in the available data, work is planned to be undertaken on well-characterized rock sections from Adamello and Bergell.

\subsection{Actinide-doped synthetic samples}

At JAERI, Synroc, perovskite and zirconolite containing about $2 \mathrm{wt} \% \mathrm{Cm}$ have been fabricated. Physical properties were monitored and some leach testing has been completed. At this stage, the work with actinidedoped zirconolite has not been completed but initial data suggests that total curium leach rates (i.e. leachate + vessel wall contributions) in deionized water from the damaged sample, after 50 and 430 years of equivalent storage age, were about $10^{-3} \mathrm{~g} \mathrm{~m}^{-2} \mathrm{~d}^{-1}$. Leach tests at ANSTO revealed that samples containing $0.0004 \mathrm{wt} \%{ }^{244} \mathrm{Cm}$ had total $\mathrm{Cm}$ leach rates that were 1 to $2 \times 10^{-5} \mathrm{~g} \mathrm{~m}^{-2} \mathrm{~d}^{-1}$, i.e. a factor of 100 lower than those obtained for the radiation-damaged specimens. At this stage, the possibility of $\mathrm{Cm}$ leach rates being enhanced by a mechanism associated with the high $\alpha$ content, e.g. a radiolysis surface mechanism, cannot be ruled out. Previous work on glass leaching has indicated this phenomenon [17], but it was not possible to ascertain whether the enhanced leaching was due to interactions between the $\alpha$-activity and the water or the teflon sample container.

Leach rates of $\mathrm{Ca}$ and $\mathrm{Pu}$ for $\mathrm{Cm} / \mathrm{Pu}$-doped zirconolite [18] that had been rendered aperiodic were a factor of 10 higher than for annealed samples, although the leach rates of $\mathrm{Cm}$ or $\mathrm{Ti}$ did not change. However, the sample used in these tests was not fully densified before or after radiation damage and after leaching it was annealed preparatory to further leach testing. So both the previous leaching of the sample and the annealing could have led to the lower leach rate. In the same study it was found that the $\mathrm{pH}$ of the leachates from $\mathrm{Cm}$-doped apatite and pyrochlore decreased during leaching; this was attributed to radiolysis effects. Although this result was not observed for the $\mathrm{Cm}$-doped zirconolite it was thought to be present but offset by the relatively high $\mathrm{Ca}$ leach rate (which could have been increased by $\mathrm{Ca}$ exchange with protons).

At this stage, it is not possible to ascertain whether the accelerated radiation damage or other mechanisms have contributed to the enhanced leach rates. However, at ANSTO, samples containing variable levels of curium doping will be used to check this phenomenon. Until the mechanism for the enhanced leaching from accelerated damage samples is established, it is not possible to extrapolate these results to the performance of ceramic wasteforms under repository conditions. Obviously the resolution of this point is of paramount importance, not only to support the argument that the natural zirconolites are performing as an analogue of the ceramic wasteforms, but also to determine the behaviour of ceramic wasteforms under repository conditions.

\section{Geochemical interactions}

The term geochemical interactions has been used in this paper to describe the overall interaction of the wasteform or natural analogue with all aspects of the natural environment. A number of the natural zirconolite samples described in the literature [3] were obtained as single grain samples or as detrital pebbles and have not been studied in situ. However, zirconolite samples from Phalaborwa, Bergell and Adamello locations can be studied in conjunction with their host rock to better define geochemical interactions [4].

In the Adamello contact aureole (Italy), zirconolite has been found in two zones (the phlogopite and the titanian clinohumite zone) of a hydrothermal vein occurring in dolomite marbles. In the phlogopite zone it is found to be corroded, but not in the titanian clinohumite zone [9]. The crystal chemical data show that zirconolite in the corrosion zones is depleted in $\mathrm{U}$ and Th. These geologically young $\left(4 \times 10^{7}\right.$ years) zirconolite crystals have been corroded by a reducing P-, S-, $\mathrm{Cl}-$, and F-rich fluid at $P=2 \mathrm{kbar}$ and $T=500-$ $600^{\circ} \mathrm{C}$, probably close (i.e. within $2 \mathrm{my}$ ) to the time of their formation. Zirconolite dissolved by the fluid was replaced by a later generation of zirconolite having a different composition. It should be noted that subsequently these zirconolites, like the uncorroded samples in the adjacent vein zones which have been rendered aperiodic, have not been corroded and do not show any loss of $U$ or Th. In addition, this corrosion has taken place at $P-T$ conditions well above those expected for a nuclear waste repository. Aggressive leaching, using $9 \mathrm{M} \mathrm{HCl}$, of samples from the phlogopite zone [19] has shown that less than $20 \%$ of the actinide elements dissolved and that there is no significant disequilibrium between U-isotopes in the U-decay chain or differences between the leaching behaviour of ${ }^{230} \mathrm{Th}$ and ${ }^{232} \mathrm{Th}$.

Another example, of zirconolite alteration is of a $2.06 \times 10^{9} \mathrm{yr}$ old sample from Phalaborwa, South Africa. AEM showed that, apart from small polycrystalline areas, most of the specimen had been rendered aperiodic at a dose level of $2-3 \times 10^{20} \alpha \mathrm{g}^{-1}$. The polycrystalline regions have experienced a similar dose to the aperiodic matrix and thus may represent a localized recrystallisation effect. The sample has undergone localized alteration along microfractures resulting from radiation damage, accompanied by migration of radiogenic $\mathrm{Pb}$. Loss of actinides has not occurred from this sample. The deficit in $\mathrm{PbO}$ is exhibited by altered and unaltered areas, consistent 
with a model of long-term $\mathrm{Pb}$ loss by diffusion. An equivalent bulk $\mathrm{PbO}$ of $2.2 \mathrm{wt} \%$ was also determined, somewhat higher than the corresponding value of $1.34 \mathrm{wt} \%$ calculated from the bulk Th $+\mathrm{U}$ levels. This result indicates that some $\mathrm{Pb}$ may have been added to the system by transport in the Si- and S-bearing ground water or fluid [9].

At this stage, the conditions under which the Phalaborwa sample was altered are not known. To provide this information, detailed isotopic studies on altered and unaltered areas of the specimens will be undertaken. Such detailed studies are required to quantify the conditions under which alteration has occurred to help quantify the geological/geochemical conditions under which zirconolite is stable.

\section{Conclusions}

The analysis of available data for samples of natural and synthetic zirconolite has established that there is a good chemical and radiation damage analogy between the samples. However, quantification of actinide retention and conditions under which zirconolite can be corroded is not available at this stage. So, as yet, it is not possible to use natural samples to describe the long-term durability of zirconolite as a HLW wasteform. The good correspondence between the samples that has been established thus far suggests that if further well controlled leaching experiments and isotopic studies are carried out then this information should be obtained.

\section{Acknowledgments}

The authors thank Kath Smith for her helpful discussion of the paper; Mark Blackford for assistance with AEM work; and Sammy Leung for assistance in the SEM investigations.

\section{References}

1. Blackford, M. G., Smith, K. L., Hart, K. P.: Microstructure, Partitioning and Dissolution Behaviour of Synroc Containing Actinides, Scientific Basis for Nuclear Waste Management, vol. XV, Ed. C. Sombret, 243 (1992).

2. Ewing, R. C., Weber, W. J., Clinard Jr., F. W.: Radiation Effects in Nuclear Waste Forms for High-level Radioactive Waste. Progress in Nuclear Energy 29(2), 61 (1995).

3. Oversby, V. M., Ringwood, A. E.: Lead Isotopic Studies of Zirconolite and Perovskite and their Implications for Long
Range Synroc Stability. Radioactive Waste Management, Vol. 1, 289 (1981).

4. Gieré, R., Williams, C. T.: REE-bearing Minerals in a Tirich Vein from the Adamello Contact Aureole (Italy), Contrib. Mineral. Petrol. 112, 83 (1992).

5. Lumpkin, G. R., Smith, K. L., Blackford, M. G., Gieré, R., Williams, C. T.: Determination of 25 Elements in the Complex Oxide Mineral Zirconolite by Analytical Electron Microscopy. Micron 25(6), 581-587 (1994).

6. Kesson, S. E., Ringwood, A. E.: Nucl. Chem. Waste Management 2, 53 (1981).

7. Clinard, F. W., Jr., Peterson, D. E., Rohr, D. L., Hobbs, L. W.: Self-irradiation Effects in ${ }^{238}$ Pu-substituted Zirconolite. I. Temperature Dependence of Damage. J. Nucl. Mater. 126, 245 (1984).

8. Lumpkin, G. R., Smith, K. L., Blackford, M. G.: Partitioning of Uranium and Rare Earth Elements in Synroc: Effect of Impurities, Metal Additive and Waste Loading. J. Nucl. Mater. 224, 31-42 (1995).

9. Lumpkin, G. R., Smith, K. L., Blackford, M. G., Hart, K. P., McGlinn, P. J., Gieré, R., Williams, C. T.: Prediction of the Long-term Performance of Crystalline Nuclear Waste Form Phases from Studies of Mineral Analogues. Proc. 9th Pacific Basin Nuclear Conference, Sydney, May 1-6, 1994.

10. Ewing, R. C., Haaker, R. F., Headley, T. J., Hlava, P.: Zirconolites from Sri Lanka, South Africa and Brazil. Scientific Basis for Nuclear Waste Management IV, Ed. S. V. Topp, 249 (1982).

11. Sinclair, W., Ringwood, A. E.: Alpha-recoil Damage in Natural Zirconolite and Perovskite. Geochem. J1, 15, 229 (1981).

12. Hough, A., Marples, J. A. C.: The Radiation Stability of Synroc. AEA Technology report, AEA-FS-0201(H) (1993).

13. Weber, W. J., Wald, J. W., Matzke, $\mathrm{Hj}$.: Effects of Selfirradiation Damage in $\mathrm{Cm}$-doped $\mathrm{Gd}_{2} \mathrm{Ti}_{2} \mathrm{O}_{7}$ and $\mathrm{CaZrTi}_{2} \mathrm{O}_{7}$. J. Nucl. Mater. 138, 196 (1986).

14. Clinard, F. W.: Review of Self-Irradiation Effects in PuSubstituted Zirconolite. Ceramic Bulletin 65 (8), 1181 (1986).

15. Mitamura, H., Matsumoto, S., Stewart, M. W. A., Tsuboi, T., Hashimoto, M., Vance, E. R., Hart, K. P., Togashi, Y., Kanazawa, H., Ball, C. J., White, T. J.: Alpha-decay Damage Effects in Curium-doped Titanate Ceramic Containing Sodium-free High-level Nuclear Waste. J. Am. Ceram. Soc. 77(9), 2255 (1994).

16. Ringwood, A. E., Kesson, S. E., Reeve, K. D., Levins, D. M., Ramm, E. J.: Synroc. In: Radioactive Waste Forms for the Future, Eds. W. Lutze and R. C. Ewing, 233 (1988).

17. Vernaz, E. Y., Godon, N.: Leaching of Actinides from Nuclear Waste Glass: French Experience. Materials Research Society Proc., Vol. 257, 37 (1992).

18. Wald, J. W., Weber, W. J.: Effects of Self-Radiation Damage on the Leachability of Actinide-Host Phases. In: Advances in Ceramics, Vol. 8, Nuclear Waste Management, Wicks, G. G. and Ross, W. A. (Eds.), pp. 71-75 (1984).

19. Payne, T. E., Lumpkin, G. R., McGlinn, P. J., Hart, K. P.: Application of a Selective Phase Extraction Procedure to Samples from the Adamello Contact Aureole (Italy). Scientific Basis for Nuclear Waste Management XVIII, Eds. T. Murakami and R. C. Ewing, 1259 (1995). 